\title{
PENGEMBANGAN MODEL PEMBERDAYAAN PEREMPUAN DESA WISATA MELALUI PENDIDIKAN BERBASIS KOMUNITAS
}

\author{
Sujarwo, Tristanti, dan Fitta Ummaya Santi \\ Universitas Negeri Yogyakarta \\ Email: sujarwo@uny.ac.id
}

\begin{abstract}
Abstrak
Penelitian ini bertujuan untuk: 1) mengimplementasikan model pemberdayaan perempuan desa wisata melalui pendidikan berbasis komunitas wirausaha jasa kuliner, 2) mengetahui hasil pelaksanaan model pemberdayaan perempuan desa wisata melalui pendidikan berbasis komunitas wirausaha jasa kuliner di Desa Wisata Bejiharjo Karangmojo. Metode penelitian yang dipergunakan adalah metode penelitian dan pengembangan atau Research \& Development (R\&D). Hasil penelitian adalah: 1) Pendidikan Berbasis Komunitas Wirausaha kuliner ini dilaksanakan melalui beberapa tahapan, yaitu: a). Sosialisasi kegiatan, b) Pelaksanaan kegiatan berupa Implementai model pendidikan berbasis komunitas wirausaha jasa kuliner dan Focus Group Discussion (FGD), dan c) Evaluasi. 2) Penerapan Model Pemberdayaan perempuan desa wisata melalui pendidikan berbasis komunitas wirausaha jasa kuliner memberikan hasil sebagai berikut: menambah motivasi peserta, cara memelihara pelanggan, cara mengelola usaha yang produktif, dan keterampilan memasak.
\end{abstract}

Kata Kunci: Desa wisata, perberdayaan perempuan, kelompok usaha kuliner, pendidikan berbasis komunitas

\section{THE DEVELOPMENT OF TOURISM VILLAGE WOMEN'S EMPOWERMENT MODELS THROUGH COMMUNITY-BASED EDUCATION}

\begin{abstract}
This study aims to: 1) implement the model tourism village women's empowerment through community-based education entrepreneur culinary services, 2) find out the results of implementation of the empowerment model tourism village women through communitybased education entrepreneur culinary services at the Tourism Village Bejiharjo Karangmojo. The research method used is a method of research and development or Research \& Development $(R \& D)$. The results of the research are: 1) Community-Based Education Culinary Entrepreneurship is implemented through several stages, namely: a). Socialization activities, $b$ ) Implementation of activities such as community-based education model Implement entrepreneurial culinary services and Focus Group Discussion (FGD), and c) Evaluation. 2) Application of Model Empowerment of rural women through community-based education travel entrepreneurial culinary services provide results as follows: increase the motivation of the participants, how to maintain customers, how to manage a productive business, and cooking skills.
\end{abstract}

Keywords: tourist village, empowerment of women, culinary business groups, communitybased education

\section{PENDAHULUAN}

Transformasi masyarakat menuju ke arah masyarakat madani perlu diawali pemahaman bahwa masyarakat sebagai sistem sosial yang di dalamnya terdapat aspek struktural, kultural dan prosesproses sosial. Perubahan masyarakat tidak akan terjadi tanpa adanya perubahan struktural yang dipengaruhi oleh faktor internal dan eksternal masyarakat itu 
sendiri. Aspek struktural meliputi segala bentuk tatanan organisasi dan kelembagaan masyarakat. Aspek cultural yang menjadi faktor penyebab perubahan masyarakat, antara lain adalah perubahan aspirasi masyarakat yang dapat diakselerasi dengan perekayasaan perubahan struktural (Irmawita, 2013:95).

Perubahan masyarakat ke arah masyarakat madani (civil society) dapat dilakukan melalui kegiatan pemberdayaan masyarakat dalam bentuk pendidikan berwawasan kemasyarakatan, pengembangan organisasi, peningkatan kesejahteraan keluarga dan pengembangan ekonomi kerakyatan. "Hubungan pendidikan dan masyarakat yang mencakup hubungan pendidikan dengan perubahan sosial, tatanan ekonomi, tatanan politik dan Negara. Oleh karena pendidikan itu terjadi di masyarakat dengan sumber daya masyarakat dan untuk masyarakat maka pendidikan dituntut untuk mampu memperhitungkan dan melakukan antisipasi terhadap perkembangan sosial, ekonomi dan politik dan kenegaraan secara simultan. Di samping itu pendidikan secara mikro harus memperhitungkan individualitas dan perbedaan karakteristik peserta didik.

Pemberdayaan masyarakat

khususnya perempuan adalah suatu proses di mana masyarakat, khususnya perempuan yang kurang memiliki akses kepada sumber daya pembangunan didorong untuk makin mandiri dalam mengembangkan perikehidupannya. Selain dari itu perempuan dituntut mampu dalam menemukan solusi yang tepat dan mengakses sumber daya yang diperlukan, baik sumber daya eksternal maupun sumber daya milik masyarakat itu sendiri. Kegiatan pemberdayaan perempuan ditentukan oleh masyarakat, dimana lembaga pendukungnya hanya memiliki peran sebagai fasilitator. Kelompok sasaran utama pendekatan pemberdayaan perempuan pedesaan adalah kelompokkelompok marginal dalam masyarakat. Astuti dkk (2008) menyatakan bahwa kebutuhan perempuan pedesaan untuk meningkatkan partisipasinya di bidang pembangunan pariwisata cukup bervariasi berdasarkan karakteristik potensi desa dan masyarakatnya. Beberapa kebutuhan tersebut antara lain pendidikan dan pelatihan serta penyuluhan dan bimbingan di bidang pengembangan atraksi/daya tarik seperti pertunjukan kesenian daerah, penyediaan homestay, pengetahuan dan ketrampilan di bidang usaha pariwisata seperti pembuatan souvenir, usaha katering, penyediaan sarana telekomunikasi/wartel, kesehatan, serta pengembangan usaha jasa pariwisata lainnya. Peluang yang tersedia bagi perempuan pedesaan wisata dalam meningkatkan partisipasinya di bidang pembangunan pariwisata cukup beragam antara lain membuka jasa akomodasi (penginapan) berupa homestay di desadesa tujuan wisata, mengemas hasil pertanian menjadi paket oleh-oleh khas, membudidayakan tanaman hias untuk dijadikan oleh-oleh wisatawan, menyajikan hasil pertanian sebagai produk makanan khas, membuka warung makan, membuat cendera mata, membuka kios cendera mata, menyediakan jasa pemanduan wisata, membentuk kelompok seni pertunjukan yang melibatkan perempuan, membuka jasa katering, dan lain-lain.

Perempuan pedesaan menghadapi beberapa permasalahan dalam meningkatkan partisipasinya di bidang pembangunan pariwisata antara lain berupa terbatasnya profesionalisme untuk mengelola kegiatan usaha yang mendukung bidang pariwisata, Faktor produksi dan pemasaran produk masih terbatas atau kurang lancar; latar belakang budaya dan persepsi sebagian masyarakat pedesaan yang masih bias gender; keterbatasan dana untuk menyediakan sarana dan prasarana objek wisata, kerjasama dan koordinasi antar sektor/instansi yang kurang intensif sehingga pemberdayaan perempuan pedesaan di bidang pariwisata ini masih kurang optimal pelaksanaannya. Sebagian 
besar perempuan desa tidak memiliki keterampilan yang berarti untuk mencari nafkah. Bagi mereka yang memiliki keterampilan, ternyata juga merasa bahwa keterampilan yang telah dimiliki masih belum cukup untuk dapat digunakan sebagai modal berusaha.

Kaitannya dengan hubungan sosial, Sujarwo dan Lutfi Wibawa (2013:8) dalam penelitiannya menemukan bahwa masyarakat Desa Bejiharjo, Kecamatan Karangmojo, Kabupaten Gunung Kidul pada umumnya menganut paham patrilineal yang menyebabkan laki-laki memiliki dominasi yang sangat kuat. Perempuan adalah masyarakat "kelas dua" yang seringkali tidak dapat memperoleh hak-haknya sebagaimana mestinya. Kondisi perempuan ibu rumah tangga di daerah ini, lebih banyak mengurus rumah, tanah pekarangan, sawah dan anak-anak di rumah, kalaupun ada sebagian perempuan ibu rumah tangga yang bekerja sifatnya hanya membantu suaminya mengurus lahannya sendiri atau ikut gotong royong membantu pengerjaan lahan tetangga.

Lebih lanjut dalam penelitiannya Sujarwo dan Lutfi Wibawa (2013:9) menemukan bahwa sistem nilai dan norma yang dianut oleh masyarakat desa Bejiharjo Kecamatan Karangmojo, masih sangat kental dengan tradisi atau adat istiadat yang berlaku di desa ini. Upacaraupacara adat, seperti; rasulan, "resik desa", upacara kematian (tiga hari, tujuh hari, empat puluh hari, seratus hari, seribu hari dan sebagainya). Peran isteri dalam keluarga mengasuh anak-anak, menjaga rumah dan harta yang dimiliki, membantu pekerjaan suami. Sehingga yang bertanggung jawab penuh mencarai nafkah adalah suami.

Masyarakat di daerah ini khususnya ibu-ibu rumah tangga memiliki keterampilan yang masih rendah, khususnya yang berkaitan dengan pengolahan sumber daya alam yang ada. Keterampilan-keterampilan yang dimiliki belum dimiliki dengan baik, sehingga perlu dilakukan pelatihan keterampilan dan kecakapan terhadap pemanfaatan sumber daya yang ada guna meningkatkan keterampilan-keterampilan usaha ekonomi produktif. Desa Bejiharjo Kecamatan Karangmojo merupakan salah satu desa wisata yang memiliki potensi wisata "Gua Pindul" dan potensi wisata sumber daya alam yang mulai dikenal oleh wisatawan lokal dan internasional, sehingga perempuan dapat diberdayakan sesuai dengan potensi daerah yang dimiliki, Selain itu upaya optimalisasi kelompok belajar dan organisasi ekonomi di desa tersebut perlu diberdayakan untuk mendukung peningkatan pendapatan masyarakat, khususnya perempuan ibu rumah tangga.

Di samping beberapa permasalahan tersebut, dalam penelitiannya, Sujarwo dan Lutfi Wibawa (2013:9) juga menemukan potensi yang dimiliki desa wisata Bejiharjo Kecamatan Karangmojo. Banyak potensi yang dapat dimanfaatkan untuk memberdayakan perempuan terutama ibuibu rumah tangga yang tidak bekerja di Bejiharjo, antara lain; optimalisasi pemanfaatan sumber daya alam (lahan dan wisata), sumber daya manusia (membantu dalam kegiatan pendidikan dan pelatihan keterampilan kewirausahaan, memperluas akses dan jejaring sosial), karakter budaya (nilai rasa kebersamaan dan kegotongan yang kuat, wisata budaya, wisata religi dan adat), organisisasi ekonomi, organisasi kemasyarakatan, jejaring sosial dan modal sosial yang sangat potensial untuk dikembangkan.

Dari berbagai analisis permasalahan tersebut, model yang dikembangkan yaitu model pemberdayaan masyarakat melalui pendidikan berbasis komunitas kuliner. Pengumpulan data awal mengenai kondisi dan potensi masyarakat sasaran, membuat program, memberikan pelatihan dan pendampingan program. Hasil dari penelitian tahun pertama adalah tersusunnya panduan program pelatihan pengembangan jasa kuliner. Panduan tersebut telah diujicobakan melalui beberapa tahapan uji coba ahli bahan ajar, maupun uji coba kepada peserta didik dengan hasil dalam kategori sangat baik, 
sehingga panduan tersebut layak untuk disebarluaskan dan diimplementasikan dalam pemberdayaan perempuan di desa Bejiharjo.

Penelitian dalam tahap dua ini adalah implementasi model pemberdayaan perempuan desa wisata Bejiharjo melalui pendidikan berbasis komunitas berwirausaha pengelolaan jasa kuliner berdasarkan panduan program pelatihan. Penggunaan panduan yang akan memberikan banyak manfaat antara lain memperjelas pesan yang disampaikan, mengatasi keterbatasan indera, ruang dan waktu, mengatasi sikap pasif dari peserta didik dan memberikan pengalaman yang menarik dan beragam. Selain itu juga dimaksudkan untuk mengetahui kebermaknaan buku panduan dalam kegiatan pembelajaran di komunitas belajar.

\section{METODE}

Penelitian dilaksanakan di desa wisata Bejiharjo Kecamatan Karangmojo Kabupaten Gunung kidul. Subjek penelitian ini adalah ibu-ibu rumah tangga usia produktif yang potensial untuk dikembangkan.

Metode penelitian yang dipergunakan adalah metode penelitian dan pengembangan atau Research \& Development (R\&D). Metode penelitian dan pengembangan merupakan metode yang dipergunakan untuk menghasilkan suatu produk dan menguji keefektifan produk tersebut sesuai dengan tujuan pengembangan. Pengembangan model pemberdayaan dilakukan dengan prosedur pengembangan model Borg and Gall yang dimodifikasi.

Prosedur penelitian dan pengembangan menurut Gall, Gall \& Borg (2003:772) pada dasarnya terdiri atas dua tujuan utama, yaitu: 1) mengembangkan produk, dan 2) menguji keefektifan produk dalam mencapai tujuan. Prosedur atau langkah kerja dalam penelitian ini meliputi; 1) penelitian pendahuluan, 2) membuat disain, 3) produksi panduan kegiatan dan pembelajaran, serta 4) uji coba produk.

Data yang dikumpulkan dalam penelitian pengembangan ini meliputi data kondisi awal, penilaian ahli media, penilaian peserta didik, serta uji coba pemakaian terbatas. Teknik pengumpulan data yang dipergunakan adalah observasi/wawancara, dan angket. Instrumen yang dipergunakan dalam pengumpulan data pada penelitian ini meliputi lembar observasi, dan lembar kuesioner. Lembar observasi untuk mencatat informasi-informasi dari lapangan (tutor), serta mencatat peristiwaperistiwa penting yang terjadi pada saat uji coba terbatas. Kuesioner dipergunakan untuk mengumpulkan data mengenai pengetahuan dan keterampilan peserta sebelum dan sesudah mengikuti pelatihan.

Data dalam penelitian awal, penilaian ahli materi dan ahli media, uji coba terbatas, serta uji keefektifan kemudian dianalisis dan dideskripsikan. Pada tahun kedua ini teknik analisis data yang digunakan dengan teknik deskriptif analitis. Data dan informasi dikelompokan sesuai dengan indikator yang ditetapkan berdasarkan panduan yang telah disusun dan diperkuat dengan Focus Group Disccusion (FGD) untuk memperdalam hasil dan permasalahan yang dihadapi peserta pelatihan setelah kegiatan pelatihan wirausaha jasa kuliner selesai.

HASIL

Implementasi Model Pemberdayaan Perempuan Desa Wisata Melalui Pendidikan Berbasis Komunitas Wirausaha Jasa Kuliner

Model pemberdayaan perempuan di desa wisata Bejiharjo, Karangmojo dilakukan melalui pendidikan komunitas wirausaha jasa kuliner. Ketersediaan potensi lingkungan dan sumber daya alam menjadi motivasi bagi komunitas dalam meningkatkan diri secara mandiri. Dengan potensi lokal yang beranekaragam dapat, jika komunitas dapat memanfaatkan dan mengolahnya secara optimal, maka akan meningkatkan keberhasilan dalam pemberdayaan perempuan. Model 
pemberdayaan perempuan ini diawali dengan uji coba produk awal yang dilakukan kepada ahli materi (content expert) dan ahli bahan ajar. Dari hasil uji coba tersebut maka diperoleh panduan pelaksanaan model pemberdayaan perempuan desa wisata melalui pendidikan berbasis komunitas.

Pelaksanaan model pemberdayaan perempuan Desa wisata melalui pendidikan berbasis komunitas wirausaha jasa layanan kuliner melalui tiga tahapan, yaitu:

a. Perencanaan. Pada tahap perencanaan ini kegiatan yang dilakukan adalah:

1) Sosialisasi Program. Kegiatan sosialisasi program dilakukan di lokasi Wirawisata Gua Pidul Desa Bejiharjo, Gunungkidul dengan memperkenalkan program kegiatan dan meminta masukan teknis terkait dengan pelaksanaan program. Sosialisasi dilakukan dengan melibatkan: calon peserta, perangkat desa, pengelola wisata dan nara sumber (pelaku usaha dan pakar).

2) Pemilihan Peserta. Peserta yang akan diberdayakan pada program ini adalah perempuan yang menjadi anggota warga masyarakat yang telah berwirausaha jasa kuliner (makanan siap saji dan oleh-oleh) di wirawisata gua pindul yang berjumlah 25 orang yang terdiri dari 4 komunitas kuliner di Bejiharjo.

3) Tujuan Program. Tujuan Program ini yaitu: a) agar perempuan memiliki pengetahuan dan keterampilan sikap dalam mengelola potensi yang dimiliki khususnya dalam berwirausaha jasa kuliner, b) meningkatkan partisipasi perempuan desa wisata dalam pengelolaan potensi lokal sebagai daya dukung wisata untuk meningkatkan pendapatan perempuan.

4) Materi. Materi pelatihan dan pendampingan dalam kegiatan pemberdayaan perempuan desa wisata melalui pendidikan berbasis komunitas meliputi: a). Motivasi dan sikap mental berwirausaha, b). Manajemen pengelolaan wirausaha kuliner, c) keterampilan usaha kuliner (aneka masakan) dan pendampingan awal dalam berusaha.

5) Strategi. Strategi merupakan prosedur panataan cara-cara penyampaian materi dan penggalian informasi dalam mencapai tujuan pelatihan. Strategi yang diterapkan pada pendidikan berbasis komunitas ini adalah pelatihan. Secara operasional startegi pembelajaran yang diterapkan dalam pelatihan ini meliputi: strategi problem solving, pembelajaran berbasis pada pengalaman, dan learning by doing. Metode yang digunakan: ceramah, diskusi kelompok, demontrasi, praktek, dan mentoring.

Langkah-langkah

pendidikan berbasis komunitas dilakukan dengan penerapan pendekatan partisipatif. Pendekatan partisipatif, yakni dengan memanfaatkan pengalamanpengalaman peserta pelatihan sebagai sumber belajar untuk terlibat dalam kegiatan pelatihan. Metode penyelenggaraan pelatihan menggunakan pola individual dan kelompok. Pelatihan dibagi dalam kelompk besar dengan jumlah 25 orang. Sedangkan pada saat praktik, warga belajar dibagi dalam kelompok kecil yang terdiri dari 5 anggota kelompok. Teknik yang digunakan meliputi: ceramah, tanya jawab, curah pendapat, diskusi, demonstrasi, simulasi, praktek, dan penugasan.

Kegiatan pelatihan ini terdiri dari 3 tahapan, yaitu: 1) Pendahuluan, meliputi: bina suasana, motivasi, dan persepsi. 2) Kegiatan inti: penyampaian materi, pengenalan alat dan bahan, prosedur praktek, praktek, dan mentoring (pendampingan). 3) Penutup, yaitu mereview dan membuat kesimpulan dari hasil pelatihan.

6) Media. Media yang dibutuhkan dalam kegiatan pelatihan dan pendampingan ini meliputi: laptop, LCD, bahan dan alat memasak. Bahan yang dipersiapkan 
dalam kegiatan praktek meliputi: daging ayam, sayuran, dan gandum. Sementara alat pendukung jasa kuliner yang lainnya meliputi: kotak, plastik, staples, alat tulis.

7) Bahan Ajar. Bahan ajar diperlukan untuk memberikan panduan kepada peserta dalam mengikuti kegiatan pelatihan dan pelaksaan praktek lapangan. Bahan ajar dalam kegiatan pelatihan wirausaha dalam bentuk anduan berwirausaha jasa kuliner yang disusun berdasarkan karakteristik dan potensi lokal.

8) Penilaian. Penilaian yang dimaksud pada kegiatan ini dilakukan dalam bentuk monitoring dan evaluasi kegiatan. Monitoring dilakukan selama kegiatan pelatihan (teori dan praktek) sampai pada tahap pendampingan.

\section{Pelaksanaan}

Pelaksanaan pendidikan berbasis komunitas ini dilaksanakan melalui beberapa tahapan, yaitu:

1) Sosialisasi kegiatan; Sosialisasi kegiatan merupakan langkah untuk menjaring peserta di komunitas Kuliner di Desa Wisata Bejiharjo agar dapat terlibat secara penuh dalam implementasi program yang akan dilaksanakan. Selain itu, sosialisasi juga dimaksudkan untuk mengadakan kesepakatan terkait dengan waktu dan tempat dimana pelatihan akan diselenggarakan. Dalam melakukan sosialisasi ini peneliti bekerjasama dengan ketua Pokdarwis di Desa Bejiharjo untuk ikut andil menentukan waktu pelaksanaan. Berdasarkan kegiatan sosialisasi ini, maka disepakati pelaksanaan kegiatan pada hari Sabtu, 23 Juli 2016 dan pelaksanaan FGD pada hari Sabtu, 20 Agustus 2016.

2) Pelaksanaan

Kegiatan Implementasi Model Pemberdayaan Perempuan Desa Wisata telah dilaksanakan pada Sabtu, 23 Juli 2016. Kegiatan ini dilaksanakan di Wirawisata dengan materi pelatihan yaitu: a) motivasi dan sikap mental berwirausaha, b) manajemen pengelolaan kuliner, c) praktek keterampilan usaha kuliner dan pendampingan awal dalam berusaha.

Materi motivasi dan sikap mental berwirausaha disampaikan oleh Dr. Sujarwo, M. Pd dan Bapak Zulkarnaen. Dalam penyampaiannya dijelaskan bahwa sukses tidaknya suatu kelompok wirausaha tergantung dari aktivitas dan kreativitas sumber daya manusianya, yang paling utama yaitu kekuatan motivasi harus dimiliki oleh calon wirausaha. Adapun kekuatan motivasi terdiri dari; 1) kekuatan keyakinan yaitu kekuatan yang paling mendasar dalam diri manusia, 2) kekuatan organisatoris yaitu bagaimana seseorang melakukan tugas dengan manajemen yang baik, 3) kekuatan intelektual yaitu jika seseorang memiliki intelektual tinggi maka orang akan lebih termotivasi dalam melakukan tugas yang dipercayakan kepadanya, 4) kekuatan teknokrat yaitu kaitannya dengan teknologi dimana semakin kuat penguasaan seseorang terhadap teknologi maka akan semakin teramotivasi dalam melaksanakan tugas itu, 5) kekuatan demokratik yaitu kaitannya dengan sikap atau gaya seseorang dalam sebuah tim, 6) kekuatan jiwa atau taqwa yaitu kekuatan yang paling menentukan kelima kekuatan di atas dan kekuatan ini semacam perintah untuk melakukan tugas sebaik-baiknya, bahkan digambarkan sebagai motivasi hidup. Sikap motivasi akan mempengaruhi sikap mental seseorang dalam berwirausaha. Sikap mental berwirausaha dapat diawali dengan belajar melalui berbagai sumber belajar yang ada di sekitar kita dengan memanfaatkan potensi lokal. Tahap selanjutnya yaitu sering berlatih dengan pengalaman-pengalaman yang diperoleh dari belajar. Kemudian bertindak atau melakukan aksi sesuai dengan rencana-rencan yang telah didesain. Pada tahapan terakhir maka 
akan diperoleh kesuksesan secara berkelanjutan.

Materi selanjutnya disampaikan oleh Bapak Zulkarnaen mengenai manajemen pengelolaan kuliner. Bapak Zulkarnaen merupakan pemilik resto di kampong Baron yang telah berhasil membangun jasa kuliner. Beliau mengawali materi dengan memberikan motivasi kepada peserta pelatihan melalui berbagi pengalamannya membangun resto di Baron. Menurutnya, bisnis kuliner akan berhasil apabila didukung dengan manajemen yang baik. Selain itu juga perlu kerjasama yang kompak antar semua anggota kelompok/komunitas kuliner. Setiap kelompok harus memiliki tugas dan perannya masingmasing. Sebagai contoh ketika mendapatkan sebuah pesanan dalam jumlah besar, maka setiap anggota hanya mengerjakan sesuai dengan tugasnya saja (tugas memasak, tugas menerima pesanan, tugas mengantar, tugas mengepak dll.), sehingga tidak terjadi double job. Dengan demikian saling kerja sama yang baik akan mendukung pengembangan kuliner. Upaya yang perlu ditempuh untuk meningkatkan layanan kuliner yaitu meningkatkan mutu dan kualitas layanan. Mutu dan kualitas layanan itulah yang menjadi daya tarik orang untuk menggunakan jasa kuliner dari komunitas tersebut. Mutu dan kualitas dapat meliputi: kualitas rasa, kualitas harga, teknik penyajian, dan kebersihan. Bahwa keberhasilan tersebut juga harus didukung oleh sarana prasarana yang komplit. Komunitas juga harus mengupayakan tempat khusus untuk mengolah makanan, tidak bercampur dengan dapur di rumah.

Materi keterampilan usaha kuliner dan pendampingan awal dalam berusaha disampaikan oleh Bapak Yadi. Komunitas ini diajak untuk mempraktekkan satu menu yaitu membuat capcay dan ayam goreng ala KFC. Beberapa teknik dalam memasak disampaikan oleh Bapak Yadi. Teknik memasak tersebut diantaranya: cara mencuci sayuran, cara mengiris, cara mencampur sayuran saat memasak, dan cara penyajian. Menurutnya, teknik ini penting sekali untuk diperhatikan, karena akan mempengaruhi kualitas olahan atau masakan. Komunitas jasa kuliner yang sudah terbentuk di Desa Wisata Bejiharjo sudah memiliki pengalaman dalam mengolah makanan lokal, akan tetapi pengalaman tersebut tidak akan bertambah dengan baik jika tidak dikembangkan melalui latihan secara terus menerus. Dalam kegiatan ini komunitas jasa kuliner mendapatkan materi baru untuk mengembangkan jasa.

Kegiatan selanjutnya setelah adanya implementasi model pemberdayaan adalah kegiatan FGD (Focus Group Discussion) yang dilaksanakan pada hari Sabtu, 20 Agustus 2016. Dalam kegiatan FGD ini masing-masing kelompok komunitas kuliner ini menyampaikan segala permasalahan yang dihadapi selama menjalani usaha kuliner. Beberapa permasalahan tersebut diantaranya: 1) Keterlambatan kedatangan pemesan bagi wisatawan di Goa Pindul, sehingga menyebabkan makanan yang sudah siap disajikan menjadi sudah tidak fresh dan sudah dingin, 2) Perhitungan antara jumlah yang dipesan dengan kenyataannya tidak sama, sehingga menyebabkan porsi yang disajikan seringkali kurang, 3) Cara pembayaran dari pemesan kepada pihak catering seringkali pembayarannya kurang jelas, sehingga sering terjadi kerugian, karena tidak ada kesepakatan pembayaran di awal, 4). Belum ada SOP tata cara penyajian makanan dalam jumlah yang banyak atau besar, 5). Masing-masing komunitas kuliner ini belum memiliki kekhasan menu.

Melalui kegiatan FGD ini, maka didiskusikan beberapa solusi untuk meningkatkan pelayanan jasa kuliner ini agar lebih baik lagi. Beberapa solusi 
tersebut antara lain: 1) Dalam menerima pemesanan, komunitas harus mencatat secara jelas mengenai: waktu pemesanan, waktu digunakan, jumlah pemesana, dan harga; 2) Pembayaran harus dilakukan oleh pemesan, kurang lebih $50 \%$ dari harga keseluruhan; 3) Komunitas perlu membuat SOP mengenai layanan kuliner, yang meliputi: tata cara pemesanan, pembayaran, pengolahan, penyajian, dan pengepakan; 4) Masing-masing komunitas kuliner membuat paket menu dan harga, serta memiliki menu yang khas dari masing-masing kelompok yang berbeda dengan kelompok lainnya.

3) Evaluasi

Evaluasi dari kegiatan ini melalui evaluasi pengamatan (observasi) saat pelaksanaan kegiatan. Berdasarkan hasil pengamatan, ada perubahan pengetahuan dan perilaku terhadap peserta di komunitas Kuliner, Bejiharjo, Karangmojo. Kendala yang dialami oleh komunitas ini adalah: 1) minimnya peralatan penyajian, 2) penghasilan yang tidak menentu, karena tidak setiap hari ada pesanan. Untuk meningkatkan layanan di komunitas kuliner tersebut, upaya yang ditempuh dengan melakukan layanan prima, yaitu meningkatkan kepuasan pengunjung atau pemesan dengan cara meningkatkan cita rasa, kebersihan, dan kekhasan menu. Selain itu dengan mencoba melengkapi peralatan penyajian dengan membuat SOP penyajian.

\section{Hasil Pelaksanaan Pendidikan Berbasis Komunitas dalam Pemberdayaan Perempuan di Desa Wisata}

Berdasarkan hasil implementasi model yang ada data dilapangan menunjukkan bahwa model ini memberikan dampak positif terhadap kelompok sasaran. Komunitas kuliner di Desa Bejiharjo mampu memanfaatkan panduan dalam meningkatkan pengetahuan, keterampilan dan kepedulian berwirausaha jasa kuliner. Selain itu juga terjadi perubahan yang meliputi: bertambahnya motivasi dari komunitas dalam berwirausaha, bertambahnya pengetahuan dan pemahaman mengenai manajemen layanan kuliner berbasis komunitas, bertambahnya pengetahuan cara pengolahan dan penyajian makanan yang menarik.

Melalui kegiatan ini, menambah motivasi peserta dalam melakukan lusaha jasa kuliner berbasis kelompok-kelompok. Peserta berusaha lebih memahami cara memelihara pelanggan, cara mengelola usaha yang lebih produktif, memiliki keterampilan dalam memberikan layanan pada pelanggan dan memiliki keterampilan dalam mengembangkan usahanya. Salah satu pengetahuan pengalaman yang diperoleh adalah menyusun standar operasional paket-paket menu dan variasi harganya. Masing-masing komunitas telah memiliki SOP dan paket menu masingmasing.

Secara umum bahwa dengan adanya pelatihan ini kelompok sasaran semakin berdaya dalam mengembangkan diri dalam wirausaha kuliner. Baik dalam upaya memanfaatkan sumber daya alam untuk diolah, ataupun dalam manajemen usaha kuliner di Bejiharjo. Namun kelompok ini masih terkendala dengan kurangnya peralatan kuliner yang lengkap dalam upaya meningkatkan pelayanan dalam hal menyajikan menu.

\section{PEMBAHASAN}

\section{Pelaksanaan Model Pemberdayaan Perempuan Desa Wisata melalui Pendidikan Berbasis Komunitas Wirausaha Jasa Layanan Kuliner}

Model pemberdayaan perempuan berbasis komunitas yang diimplementasikan telah memberikan pemahaman, pengetahuan, dan keterampilan bagi komunitas kuliner di Bejiharjo. Pelaksanaan Pendidikan Berbasis Komunitas ini dilaksanakan melalui beberapa tahapan, yaitu a) Sosialisasi kegiatan, b) Pelaksanaan kegiatan berupa Implementasi model pendidikan berbasis komunitas dan Focus 
Group Discussion (FGD), dan c) Evaluasi. Kegiatan berjalan dengan baik dan lancar, yang diikuti oleh seluruh peserta secara menyeluruh dan sesuai dengan panduan yang telah tersusun. Peserta mengikuti secara aktif dalam kegiatan pelatihan pengelolaan wirausaha jasa kuliner. Hal ini ditunjukkan dengan sebagian besar peserta menyampaikan pengalamannya dalam mengelola usaha jasa kuliner selama ini dan menanyakan beberapa permasalahan yang dialami. Peserta berusaha memperoleh akses, perubahan sikap, pengetahuan, keterampilan usaha dan keterampilan cara mengelola usahayang dilembagakan untuk memperoleh legalitas secara yuridis. Pemberdayaan perempuan di bidang pariwisata lebih ditekankan pada: 1) organizing and managing the process yang menyangkut upaya perubahan sikap setelah sekian lama terbentuk dominasi pria di banyak bidang pekerjaan; 2) inventory process yang berkaitan dengan upaya memberikan peluang kepada perempuan untuk mengembangkan kemampuannya sehingga mereka dapat berpartisipasi di bidang pembangunan masyarakat; dan 3) delivery process yang meliputi upaya memberikan kesempatan kepada perempuan untuk berpartisipasi dan berperan di bidang pembangunan pariwisata berkaitan dengan akomodasi, restoran, biro perjalanan, dan pengembangan berbagai produk budaya berupa seni dan tradisi sebagai daya tarik wisata.

Dalam penerapannya, perlu memperhatikan beberapa hal agar mendapakan hasil yang maksimal. 1) motivasi kelompok sasaran. Membangun motivasi merupakan hal yang sangat penting dalam upaya mengubah sikap mental kelompok sasaran agar terbentuk pola pikir untuk maju dan berkeinginan untuk berubah. Motivasi menjadi dasar seseorang untuk melakukan suatu tindakan, terutama motivasi dalam bekerja. 2) memanfaatkan potensi sumber daya alam. Potensi sumber daya alam menjadi daya tarik tersendiri dalam mengembangkan masyarakat. Dengan tersedianya sumber daya alam yang melimpah, mendorong masyarakat untuk berpikir kreatif memanfaaatkan sumbersumber yang ada. Seperti di Bejiharo yang kaya akan sumber alam yang indah, yaitu Goa Pindul, Goa Tanding, dan lainnya membuat masyarakat harus kreatif mengoptimalkan sumber yang ada menjadi lahan pendapatan. Mulai dari mengelola menjadi obyek wisata, hingga berwirausaha memenuhi kebutuhan pengunjung. 3) Memperhatikan ketersediaan sumber daya manusia. Ketersediaan sumber daya manusia mendorong tercapainya suatu usaha yang maksimal. Manusia senatiasa memiliki akal dan pikiran untuk terus menerus mengembangkan diri. 4) sarana dan prasarana penunjang, dan 5) Kerjasama antar kelompok. Membangun suatu kerjasama dalam sebuah kelompok adalah penting. Suatu kelompok yang memiliki satu visi dan misi yang sama akan mudah mencapai suatu keberhasilan, dibandingkan yang jalan sendiri-sendiri. Maka dari itu, dalam berwirausaha ini kerjasama antar kelompok agar senantiasa dibina.

Dengan adanya model ini, diharapkan masyarakat terutama kaum perempuan mampu meningkatkan partisipasinya dalam pembelajaran diri dan lingkungan. Masyarakat harus diberikan kebebasan untuk berkreativitas dan berkembang sesuai dengan kondisi mayarakat tersebut. Hal ini seperti yang diungkapkan oleh Hardika (2013:114), bahwa pemberian kebebasan kepada masyarakat untuk beraktualisasi dalam belajar usaha (wirausaha) merupakan hal penting dalam upaya pemberdayaan masyarakat.

Namun demikian masih ada sebagian kegiatan yang belum berjalan secara optimal, yaitu pendampingan. Program pendampingan belum dilakukan secara optimal, hal ini dipengaruhi oleh; sangat terbatasnya waktu kegiatan, terbatasnya kemampuan dan pengalaman peneliti dalam mengelola jasa layanan jasa 
kuliner. Belum optimalnya program pendampingan ini perlu diupayakan adanya perencanaan yang matang dalam melanjutkan program pendampingan yang lebih optimal. Dengan demikian akan terjadi perubahan dalam diri peserta melalui berbagai macam kegiatan yang mampu meningkatkan pengetauan, keterampilan dan kecakapan hidup lainnya.

Kondisi ini sejalan dengan pendapat Hardika (2013:115), bahwa ada beberapa prinsip pembelajaran yang harus diperhatikan dalam melakukan pemberdayaan masyarakat termasuk perempuan adalah 1) perubahan kehidupan harus disikapi sebagai proses pembelajaran, 2) belajar merupakan proses inkuiri aktif dengan prakarsa utama dari dalam diri peserta belajar, 3) belajar adalah upaya membantu kecakapan untuk kebutuhan selama hidup, 4) peserta belajar memiliki keragaman belajar yang harus digali dan dimanfaatkan, 5) sumber belajar ada di setiap lingkungan yang harus diidentifikasi untuk kemanfaatan peserta belajar, dan 6) belajar lebih berdaya guna bila dipandu dengan struktur proses yang mengakar daripada struktur isi yang tidak relevan.

\section{Hasil Pelaksanaan Pendidikan Berbasis Komunitas dalam Pemberdayaan Perempuan di Desa Wisata}

Setiap kegiatan pelatihan dan pendidikan memberikan dampak dan hasil bagi pesertanya. Melalui kegiatan ini diperoleh informasi sebagai berikut; menambah motivasi peserta dalam melakukan usaha jasa kuliner berbasis kelompok-kelompok. Peserta berusaha lebih memahami cara memelihara pelanggan, cara mengelola usaha yang lebih produktif, memiliki keterampilan dalam memberikan layanan pada pelanggan dan memiliki keterampilan dalam mengembangkan usahanya. Salah satu pengetahuan pengalaman yang diperoleh adalah menyusun standar operasional paket-paket menu dan variasi harganya. Secara sederhana dapat dinyatakan bahwa hasil dari penerapan model perberdayaan perempuan melalui pendidikan berbasis komunitas wirausaha jasa kuliner ini memberikan dampak; memberikan motivasi dalam mengelola usaha, dimilikinya pengetahuan dan keterampilan dalam mengelola usaha lebih produktif dan memperluas akses sesuai dengan potensi yang dimiliki.

Untuk menyesuaikan dengan situasi dan kondisi yang dihadapi serta potensi diri yang dimiliki peluang ini harus benarbenar dapat diakses oleh semua lapisan masyarakat dengan segala karakteristik dan atribut yang dimilikinya (Hardika, 2013:117). Pendidikan adalah suatu keniscayaan untuk membantu perkembangan kesempurnaan manusia. Oleh karena itu, bahan pembelajaran tidak dapat ditetapkan begitu saja hanya dari sudut pandang ilmu pendidikan, tetapi juga harus memperhatikan bidang-bidang lain seperti ilmu sosial, psikologi, sosiologi, sejarah, manajemen serta ilmu bantu pendidikan yang lain.

Pendidikan berbasis komunitas wirausaha jasa kuliner dimaksudkan untuk memberikan penguatan dalam kegiatan wirausaha jasa kuliner sebagai upaya meningkatkan taraf kehidupan masyarakatnya. Pendidikan berbasis masyarakat adalah sebuah proses yang didesain untuk memperkaya kehidupan individual dan kelompok dengan mengikutsertakan orang-orang dalam wilayah geografi, atau berbagai mengenai kepentingan umum, untuk mengembangkan dengan sukarela tempat pembelajaran, tindakan, dan kesempatan refleksi yang ditentukan oleh pribadi, sosial, ekonomi dan kebutuhan politik mereka.

Dalam kegiatan ini diarahkan agar peserta menjadi agen pemberdaya masyarakat khususnya kaum perempuan di dewasa wisata selanjutnya agar terjadi kesinambungan. Model pembelajaran masyarakat harus menempatkan agen pembaharu sebagai fasilitator yang berfungsi sebagai 1) catalisator (mempercepat proses terjadinya belajar); 
2) resources linker (penghubung berbagai sumber belajar); 3) process helper (pembantu proses belajar), dan 4) solution helper (pembantu pemecahan masalah belajar).

\section{PENUTUP}

Dari paparan hasil penelitian dan pembahasan dapat disimpulkan sebagai berikut: 1) Pelaksanaan model pemberdayaan perempuan desa wisata melalui pendidikan berbasis komunitas wirausaha jasa layanan kuliner. Model pemberdayaan perempuan berbasis komunitas yang diimplementasikan telah memberikan pemahaman, pengetahuan, dan keterampilan bagi komunitas kuliner di Bejiharjo. Pelaksanaan Pendidikan Berbasis Komunitas ini dilaksanakan melalui beberapa tahapan, yaitu a) Sosialisasi kegiatan, b) Pelaksanaan kegiatan berupa Implementasi model pendidikan berbasis komunitas dan Focus Group Discussion (FGD), dan c) Evaluasi. 2) Hasil Implementasi model pemberdayaan perempuan desa wisata melalui pendidikan berbasis komunitas wirausaha jasa kuliner. Penerapan model pemberdayaan perempuan desa wisata melalui pendidikan berbasis komunitas wirausaha jasa kuliner sebagai berikut; menambah motivasi peserta dalam melakukan usaha jasa kuliner berbasis kelompok-kelompok. Peserta berusaha lebih memahami cara memelihara pelanggan, cara mengelola usaha yang lebih produktif, memiliki keterampilan dalam memberikan layanan pada pelanggan dan memiliki keterampilan dalam mengembangkan usahanya. Salah satu pengetahuan pengalaman yang diperoleh adalah menyusun standar operasional prosedur (SOP) paket-paket menu dan variasi harganya.

\section{Saran}

Dari kesimpulan di atas dapat disarankan sebagai berikut: 1) bagi Pemerintah setempat. Dari pengembangan model pemberdayaan perempuan ini, pemerintah setempat dapat mengarahkan sebagian kebijakannya pada program-program pemberdayaan masyarakat khususnya untuk kaum perempuan yang bersifat pragmatis dalam bentuk keterampilan dan kecakapan hidup lainnya dengan menggandeng stakeholder atau dunia usaha dan perbankan. 2) Bagi Pemuka masyarakat, dapat memobilisasi potensi perempuan di desa wisata dan sumber daya yang ada sebagai modal dasar dalam pemberdayaan perempuan, khususnya ibu rumah tangga yang tidak bekerja agar lebih berdaya guna dalam menopang kehidupan keluarga dan masyarakat. 3) Bagi Peneliti, hasil penelitian ini dapat dilanjutkan dengan penelitian tindakan, agar dapat membantu memberdayakan perempuan, khususnya ibu rumah tangga yang tidak bekerja.

\section{DAFTAR PUSTAKA}

Gall, M. D., Gall, J. P., \& Borg, W. R. (2003). Educational Research: An Introduction, seventh edition. Boston: Pearson.

Hardika. (2013). Pergeseran Pola Kehidupan Dan Kebutuhan Belajar Masyarakat Model Prismatik. Proceding Seminar Nasional Pengembangan Masyarakat Berbasis Modal Sosial. Yogyakarta: Jurusan PLS FIP UNY.

Irmawita. (2013). Model Pemberdayaan Masyarakat Desa Berbasis

Kebutuhan Belajar. Proceding Seminar Nasional Pengembangan Masyarakat Berbasis Modal Sosial. Yogyakarta: Jurusan PLS FIP UNY. Sujarwo dan Lutfi Wibawa (2013).

Analisis Permasalahan Perempuan dan Potensi Lokal. Laporan Penelitian. Yogyakarta: Fakultas Ilmu Pendidikan UNY (laporan penelitian tidak dipublikasikan). 